\title{
Andrew Jackson Stevens and the Iowa Exploring Expedition to Ecuador
}

John N. Riismandel

FOR OVER A DECADE Andrew Jackson Stevens played an im. portant part in the political and financial life of Des Moines and Iowa, yet he is only briefly mentioned in the histories of the period. Since he left Iowa during the Civil War and never returned, his contemporaries, like F. M. Hubbell and B. F. Allen, who became the leaders of Des Moines in the 1860 s and 1870 s overshadowed him. Stevens is best remembered as a land speculator and banker. His bankruptcy during the Panic of 1857 was viewed by later historians as a just reward for his wildcat banking, and this colored the estimation of his life in Iowa. His career was perhaps typical of many in the barely settled regions in the mid-nineteenth century. Trained in the law, Stevens taught school, engaged in politics, land speculation and banking and was rewarded for his political activities with an appointment as a consul.

It is interesting that at the height of his career in Des Moines Stevens sponsored an exploring expedition by two Iowa scientists to the then remote country of Ecuador. Beyond civic pride, his motivations for sponsoring the expedition are obscure. In fact, there is no indication in his surviving records of this act. The object of this expedition was to gather botanical and zoological specimens from the unexplored Napo River region of eastern Ecuador. These were to form the nucleus of a museum in Des Moines. Scientifically, the expedition was not notable. Historically, it is of interest because it was sent from an area barely out of its frontier stage.

Andrew Jackson Stevens arrived in Des Moines when it was 
still a frontier outpost with only a few hundred inhabitants. He was a native of New York and had read law in the office of William Seward who later became Lincoln's secretary of state. Stevens' reasons for coming west and the exact date of his arrival in Des Moines are unknown. The first record of his being in Des Moines is during the winter of $1847-1848$ when he is mentioned as having taught a three-month term in the public school. ${ }^{1}$ Shortly thereafter, he took up the practice of law and entered politics. He was particularly active in the various groups which were promoting the building of a railroad through central Iowa. Stevens served as secretary at one convention held for this purpose in Des Moines in December, 1849. The following year he acted as Polk County's representative at a similar gathering in lowa City. ${ }^{2}$

In the early 1850s, Stevens was one of a group of young men who later became the political and financial leaders of Des Moines. He roomed at the Marvin House near Third and Walnut with B. F. Allen, Hoyt Sherman, William "Uncle Billy" Moore and Madison Young. It was at this time that Stevens began to participate in politics on the state level. He served on the committee which named the counties of Iowa in 1854 and subsequently won statewide election to the office of state auditor. He was auditor for only a partial term, resigning in September, 1855, to devote himself more fully to his other activities, mainly land speculation. ${ }^{3} \mathrm{He}$ did remain active in local politics, particularly in the

'In 1846, Des Moines had a population of 127. A. J. Stevens is not listed in the census taken that year. Polk County 1846 Census, Taken January 17, 1846. Alphabetized by Ethel McGlothlin,. Typescript copy in the lowa State Archives, 1966; Johnson Brigham, Des Moines. The Pioneer of Municipal Reform of the Middle West Together with the History of Polk County, Iowa, the Largest, Most Populous and Most Prosperous County in the State of Iowa, 2 vols. (Chicago: the S. J. Clarke Publishing Company, 1911), I, 112; J. M. Dixon ("Blind Editor"), Centennial History of Polk County, Iowa. Authorized by the Board of Supervisors of Polk County (Des Moines: State Register, Print., 1876), 197; Tacitus Hussey, "A History of the Banks of the Des Moines," The Midwesterner, n.p., n.d. [Separately bound aricle in the Historical Library, State of Iowa], 23-24; A. J. Stevens to W. H. Seward, Washington, D.C., October 25, 1866, Consular Records of the Department of State, (Windsor, Canada), Microfilm T-492, Reel 1.

${ }^{2}$ Brigham, Des Moines, I, 67, 107-108.

${ }^{3}$ Ibid., I, 100; L. F. Andrews, Pioneers of Polk County, Iowa and Reminiscenses of Early Days, 2 vols. (Des Moines: Baker-Trisler Company, 1908), I, 254; P.M. Casady, "The Naming of the Iowa Counties," Annals of Iowa, II, nos. 2-3 (July-October, 1895), 200; Tacitus Hussey, "The Flood of 1851," Annals of Iowa. V, no. 6 (July, 1902), 404; Tacitus Hussey, "History of Steamboating on the Des 
then new Republican Party. He was that party's representative to the National Committee and chairman of the State Central Committee in the years before the election of Lincoln. While able, he contributed generously to the party's coffers, particularly in the election of $1856 .^{4}$

Stevens also gave up the practice of law to engage in land speculation. To increase the value of Iowa farmland as well as that of his own holdings, he promoted and was a founder of the Polk County Agricultural Society. For two years, 1853-1854, he was that organization's corresponding secretary. ${ }^{5}$ The fact that Stevens engaged in land speculation is known principally from statements made about him by historians who knew him personally. The only available concrete proof of this activity is in the Land Grant Records-Polk County. Iowa. These show that at least nine veterans of the War of 1812 and Indian Wars assigned their land warrants to Stevens. What he paid for these and whether he sold the land or held it is unknown. ${ }^{\circ}$

In the histories of Des Moines and Iowa, Stevens is most often remembered as a banker. He entered banking as a means of financing his speculative activities and in the process he provided funds for others as well. In 1855, he established the Bank of Iowa in Des Moines, located on 2nd Street between Court and Vine. The next year he "induced James Callanan and S. R. Ingham, residents of New York to join him, and the banking firm of A. J. Stevens and Company was started." Like most state-chartered banks of this period, A. J. Stevens and Company issued banknotes with very little regulation. Unlike most banks, Stevens' did not issue its own notes but those of the Agricultural Bank of Ten-

Moines River from 1837 to 1862," Annals of Iowa, IV, no. 5 (April, 1900), 345; Union Historical Company, The History of Polk County, Iowa. Containing a History of the County.... Miscellaneous Matters, etc., (Des Moines: Union Historical Company, Birdsell, Williams \& Co., 1880), 174.

${ }^{4}$ W. Penn Clark to A. Lincoln, Iowa City, Iowa, June 8, 1861, Appointments of A. Lincoln and A. Johnson. Department of State Records, Microfilm M-650, Reel 47.

${ }^{5}$ Polk County Agricultural Society, Report, 1857 (Des Moines: n. pub., 1857), 391, 393.

${ }^{6}$ Land Grant Records-Polk County, Iowa, 4 vols. Prepared by the War Records Survey, Typescript in the Iowa State Archives, IV, passim.

'Andrews, Pioneers, I, 254; Brigham, Des Moines, I, 527; Dixon, Centennial, 274; H. B. Turrill, Historical Reminiscenses of the City of Des Moines, . . . (Des Moines: Redhead \& Dawson, 1857), 123. 
nessee. This of course made it difficult for the holders of these notes to redeem them for specie. One historian described Stevens' banking methods in this manner:

Down in an obscure place in Tennessee, he bought the charter of the Agricultural Bank of Tennessee, loaded himself with its beautifully engraved notes, and immediately began to unload them on the community. It was "easy come, easy go." Having the prestige of a local institution, he was enabled to loan it in large blocks, to landbuyers and speculators, taking their individual promissory notes therefor, with an agreement that he would redeem his banknotes when presented at this bank.

This system, as described here, was not unusual in the United States prior to the Civil War. In fact, it worked well as long as the issuing bank could redeem its notes for either specie or other well accepted banknotes. Also, as long as the community retained its faith in the bank, it could easily meet its obligations. When the confidence of the depositors was undermined, as it was for A. J. Stevens and Company during the Panic of 1857 , the bank had to close its doors.

As a result of the Panic, Stevens' partners forced him to sell his interest in the bank, 10,000 of 25,000 shares, to them. At this point, the bank had only 8,500 dollars on hand with which to redeem over 58,000 dollars of its notes. The historian quoted above said of this episode that "Callanan and Ingham repudiated Stevens and his business methods, ousted him from the company, and turned their attention to real estate and legitimate banking, Ingham becoming the resident member [in Des Moines] of the firm." 9

This particular episode seems to have fixed an image of Stevens as a rascal and shady operator in the minds of later historians. In the context of the 1850 s and the then prevailing methods of banking, particularly in the western areas, Stevens' activities were not unusual. After his forced retirement from banking, Stevens continued to live in Des Moines and attempted to rebuild his fortunes. Just prior to the Panic of 1857 he financed the expedition to Ecuador. It is not ascertainable from the available records just what funds he used for this purpose.

${ }^{8}$ Andrews, Pioneers, I, 254.

Ibid.; A. J. Stevens \& Company, Ledger, 1857, MS in lowa State Archives; A. J. Stevens \& Company, Journal, 1857, MS in Iowa State Archives, 3; Iowa State Journal, Des Moines, August 29, 1857, 4, September 5, 1857, 4. 
Even before the end of his banking career, Stevens had become involved in newspaper publishing, an activity he continued until he left Des Moines. His involvement in publishing was related to his political activities. In 1856 , he became the financial backer of Thomas M. Sypherd's Iowa Citizen, Des Moines' Free Soil Republican newspaper. Stevens maintained his interest in this paper until he was forced to sell out by the Panic. ${ }^{10}$ In 1859 , he became the first editor of the Iowa School Journal. Soon thereafter, he and W. H. Hoxie founded the Commonwealth as an organ for the Young Republicans. Stevens relinquished both the editorship of the Iowa School Journal and part ownership of the Commonwealth in 1861. He sold his interest in the latter paper to the Des Moines Times. ${ }^{11}$

Financial embarrassment caused Stevens to give up publishing and to seek a government job as a reward for his political activities. After repeated solicitations by himself and by others on his behalf to his old teacher, W. H. Seward, Stevens was appointed United States' Consul to Leghorn in Italy. ${ }^{12}$ Before the receipt of this appointment, Stevens apparently had served in the Union Army. In a letter recommending Stevens for a position in the government, I. M. Forbes stated that Stevens had fought in the war and been wounded. ${ }^{13}$ Another letter from the acting secretary of the Interior, W. T. Otto, referred to Stevens as a Brigadier General. ${ }^{14}$

Stevens served as Consul at Leghorn from July, 1862 until June, 1865, when, at his own request, he was transferred to a similar post at Windsor, Canada. ${ }^{15}$ While at Windsor, Stevens

${ }^{10}$ Brigham, Des Moines, I, 81; Dixon, Centennial. 186.

"Brigham, Des Moines, I, 551; Dixon, Centennial. 184, 192.

${ }^{12}$ Brigham, Des Moines, I, 551; List of United States Consular Officers. Department of State Records, Microfilm M-587, Reels 10, 21; A. J. Stevens to W. H. Seward, Des Moines, January 14, 1861, A. J. Stevens to W. H. Seward, Des Moines, June 13, 1861, Jacob Butler to A. Lincoln, Muscatine, Iowa, June 4, 1861, E. D. Morgan to A. Lincoln, Albany, N.Y., June 18, 1861, Francis Springer to W. H. Seward, Columbus City, Iowa, June 21, 1861, A. J. Stevens to W. H. Seward, Des Moines, June 23, 1861, James W. Grimes [Governor of Iowa] to W. H. Seward, n.p., n.d., in Appointments of A. Lincoln.

${ }^{13}$ I. M. Forbes to A. Lincoln, n.p., September 21, 1865, in Appointments of A. Lincoln.

${ }^{14} \mathrm{~W}$. T. Otto [Acting Secretary of the Interior] to W. H. Seward, Wash., D.C., September 30, 1865 in Ibid.

${ }^{15}$ List of United States Consular Officers. Stevens served at Windsor from 
repeatedly attempted to obtain a more prestigious position such as a territorial governorship or secretaryship. He expressed hopes of using such an office as a stepping-stone to the United States Senate, but was frustrated in this attempt. After resigning his post at Windsor in 1869, Stevens' life becomes obscure. The only available information states that he moved from Windsor to Nebraska where he again failed in banking and finally moved to California where he died. ${ }^{16}$

The two Iowans who comprised the expedition to Ecuador were William Moore and Edward Francis. Moore was a resident of Des Moines and probably was the instigator of the expedition. He was a taxidermist and collector of birds by profession. He had arrived in Des Moines in the late 1840s and soon became well known in the state for his taxidermy. ${ }^{17}$ At the Iowa State Fair of 1854, held in Fairfield, Iowa, he exhibited a "fine collection of birds." 18 An historian who must have known Moore personally, described him as "an eccentric and gifted gentleman, . . . full of genial wit and racy anecdote." ${ }^{19}$ Even less is known of the other member of the expedition, Edward Francis. Of English birth, he was a naturalized citizen of the United States, a doctor of medicine and a professor at the Medical College of Keokuk, Iowa. He

January, 1867 to April, 1869; A. J. Stevens to W. H. Seward, Washington, D.C., October 25, 1866, Windsor, November 6, 1866, A. J. Stevens to H. Fish, Detroit, June 6, 1869, Consular Records.

${ }^{16}$ A. J. Stevens to W. H. Seward, Windsor, December 18, 1868 in Appointments of A. Lincoln; Brigham, Des Moines, I, 551.

"When Moore arrived in Des Moines is not known. He is not listed in the 1846 census; Dixon, Centennial, 291; Brigham cites another early history of Iowa, Negres, "Early History of Iowa" about Moore's collection of stuffed birds. Des Moines, I, 682.

Although the direct connection between Stevens and the exploring expedition to Ecuador is slight, the fact that he sponsored it and that the expedition actually happened is important. It appears that a mixture of civic pride and scientific curiosity on the part of the two participants motivated the launching of the expedition. The sending of an expedition of such a nature to the wilds of the Amazon basin by a man like Stevens, and perhaps others in Des Moines, demonstrated that there existed even in the newly settled areas, a curiosity about and an interest in the wider world.

${ }^{18}$ The Fairfield Ledger. Fairfield, Iowa, November 2, 1854, 2. The article continued: "At his home he has a collection of all the varieties which are found in our state. He must have a peculair way of preserving them, for the birds all looked very lifelike."; Union, History, 180.

${ }^{19}$ Dixon, Centennial, 291. 
probably went on the expedition in the search of medicinal plants. ${ }^{20}$

The Iowa Exploring Expedition, as it was styled in the newspapers, left Des Moines in late 1856. Presumably, Moore and Francis traveled to New Orleans where they could have taken a ship to Panama. From there they would have crossed the Isthmus and sailed down the west coast of South America to Guayaquil, the principal port of Ecuador. From Guayaquil, they traveled overland and after an arduous journey arrived in Quito, the Ecuadorian capital, in early $1857.2^{21}$

Once in Quito, Moore and Francis reported to the United States Minister, Philo White. According to White, the two asked for his help in obtaining aid and protection from the Ecuadorian government. White complied with their request and asked the Ecuadorian government to "afford them the requisite facilities of protection in their comtemplated tour." ${ }^{22}$ The Ecuadorians agreed to provide protection, to assume the costs of the expedition and to send one of their scientists, Dr. William Jameson, Professor of Chemistry at the University of Quito, along with the two Americans. ${ }^{23}$ The Ecuadorian government aided the Iowans because at this time it was reforming its university and educational system. The Ecuadorians were curious about their own country and wanted to help anyone willing to increase their knowledge of Ecuador, particularly the unexplored regions east of the Andes. ${ }^{24}$

The three scientists accompanied by some Indians and mules set out from Quito for the Oriente region on the eastern slopes of

${ }^{20}$ Philo White to the Secretary of State, Quito, July 17, 1857 (Despatch \#120), Diplomatic Despatches, Department of State Records, Microfilm T-50, vol. 4.

"Philo White to the Secretary of State, Quito, January 16, 1857 (Despatch \#101), Ibid. For a description of the journey between Guayaquil and Quito in the mid-nineteenth century see: F. Haussaurek, Four Years Among the Spanish Americans (N.Y.: Hurd \& Houghton, 1867), 18-103. Haussaurek succeeded White as U.S. minister to Quito.

${ }^{22}$ Philo White to the Secretary of State, Quito, January 16, 1857 (Despatch \#120), Diplomatic Despatches.

${ }^{23}$ New York Times, February 26, 1857, 2. This article was dated January 10, 1857 with a dateline of Quito and was signed by Moore; Ministro de Relaciones Exteriores del Ecuador al Señor Philo White, Quito, January 8, 1857. This is a copy of the original in Diplomatic Despatches.

24ulio Tobar Donoso, "Garciá Moreno y la instrucción pública," Boletín de la Academia Nacional de Historia, Quito, IV, no. 9 (enero-febrero, 1922), 6372; Germanía de Moncayo de Monje, La Universidad de Quito: su trayectoria en tres siglos, 1551-1930 (Quito: Imprenta de la Universidad, 1944), 147. 
the Andes. In April, 1857, they reached the capital of Oriente Province and were well received by the local civil and military officials. From there they moved into the jungle and established a camp. ${ }^{25}$ Shortly after their arrival, a tragic accident interrupted their collecting and observing. On the nineteenth of April, Mopre accidentally shot Francis. The details of this accident were reported to Philo White by the Educadorian Ministry of Foreign Relations which received its information from the governor of Oriente Province. The governor did not learn of the shooting until two weeks after it had occurred because of the difficulties of travel between the Americans' camp and the provincial capital. In his report to the foreign ministry, the governor described the accident in this manner:

On the 19th of last month [April] at seven in the evening, Mr. Francis was sitting at the door of the quarters that he occupied, next to his companion,.Mr. Moore; who in the darkness of the interior of the habitation was preparing to shoot his rifle at a nocturnal bird which had on various occasions passed over their habitation, and at the same time that Moore was arranging the percussion cap, the hammer fell with force and the weapon discharged, wounding the unfortunate Mr. Francis.

The governor continued to say that Francis was still alive, although seriously wounded, and that every effort was being made to save his life.

Despite these efforts, Francis died on the fifteenth of June. After burying Francis, Moore continued collecting birds and plants as he made his way eastward to the Amazon and eventually the Atlantic, carrying the personal effects of Francis with him. ${ }^{26}$ Word of the shooting and death of Francis did not reach Iowa until September, 1857. The Iowa newspaper accounts of the incident merely copied the reports printed in the New York Times. These were written by Moore who had acted as a special correspondent for the Times during the expedition. ${ }^{27}$ In Iowa there seems to have been some suspicion about the circumstances

${ }^{25}$ Gobernador de la Provincia del Orienta al Ministro de Relaciones Exteriores del Ecuador, San Rosa, May 8, 1857. MS in the Biblioteca Ecuatoriana "Aurelio Espinosa Polit," Reel 44 of the mircrofilm copy of this collection in the Joint Universities Library, Nashville, Tennessee. Hereinafter this collection will be designated as BEAEP.

${ }^{26}$ Philo White to the Secretary of State, Quito, July 17, 1857 (Despatch \#120), October 10, 1857 (Despatch \#128), Ibid.

${ }^{2}$ New York Times. September 4, 1857, 2; Iowa State Journal, Des Moines, September 19, $1857,2$. 
of Francis' death. Although the reports of the Ecuadorian government and Philo White do not cast any aspersions on Moore, one contemporary writer commented that the incident was "of such a nature as to throw suspicion on Mr. Moore." ${ }^{28}$ At the end of 1857, Philo White, writing from Quito, attempted to set the record straight. He reported to the State Department that all reports of animosity or of a duel between Francis and Moore were completely false.

Moore arrived back in Des Moines in the Spring of 1858 and exhibited the specimens he had collected at the Savery House. Soon thereafter, his condition deteriorated. He became "discouraged and demoralized, drinking deeply and repeatedly, until . . . weary and disappointed he shook the Des Moines dust from his feet and garments, and left, never to return." The accounts of the expedition that Moore wrote for the New York Times do not indicate that he felt any great guilt over the death of Francis. The reports treat the incident as a tragic accident but only an accident.

As a lawyer, teacher, banker, politician and speculator, Andrew Jackson Stevens played an important if not crucial part in the early development of Des Moines and Iowa. Yet, he has been largely forgotten, remembered for the most part only as a less than respectable banker and speculator. This opinion results from his failure in the Panic of 1857. Contemporaries who knew Stevens primarily for his political activities, such as the Civil War governor of Iowa, thought highly of him and wrote glowing letters of recommendation for him. Perhaps a more detailed study of Stevens' life in Des Moines is needed to make a judgment but at present the materials necessary for this study have not been found.

In and of itself, the Iowa Exploring Expedition to Ecuador is not of great significance. The scientific value of the specimens collected and observations made by the three scientists was not great either. Yet, it is significant that such an expedition was sent at all from a town just emerging from the frontier. It demonstrates that men like A. J. Stevens, William Moore and Edward Francis were interested in the wider world and willing to risk money and even their lives for the sake of expanding the frontiers of knowledge.

${ }^{20}$ Dixon, Centennial, 292. 
Copyright of Annals of Iowa is the property of State of Iowa, by \& through the State Historical Society of Iowa and its content may not be copied or emailed to multiple sites or posted to a listserv without the copyright holder's express written permission. However, users may print, download, or email articles for individual use. 